\title{
ANALISIS KOMPETENSI SOSIAL MAHASISWA FKIP PGSD UNIVERSITAS WIDYAGAMA MAHAKAM SAMARINDA 2018
}

\author{
Desi Hermawati, Eka Selvi Handayani \\ Universitas Widyagama Mahakam Samarinda \\ mb.desy76@gmail.com \\ ekaselvi86@gmail.com
}

\begin{abstract}
ABSTRAK
Tujuan penelitian ini adalah untuk mendeskripsikan kompetensi sosial mahasiswa PGSD UWGM sebagai calon guru di Sekolah Dasar. Penelitian ini merupakan penelitian kualitatif. Subyek dalam penelitian ini adalah mahasiswa PGSD Universitas WIdya Gama Mahakam Samarinda angkatan 2015. Teknik pengumpulan data yang digunakan adalah observasi, wawancara mendalam, dan dokumentasi. Sesuai dengan metode kualitatif, teknik analisis data yang digunakan adalah teknik analisis Model Miles and Huberman. Aktivitas dalam analisis ini meliputi reduksi data (data reduction), penyajian data (data display) serta Penarikan kesimpulan dan verifikasi (conclusion drawing / verification). Hasil penelitian menunjukkan bahwa pemahaman mengenai kompetensi social mahasiswa PGSD sangat baik yaitu 91,9\%. 89\% mahasiswa menyatakan setuju bahwa seorang guru harus memiliki kemampuan berkomunikasi yang efektif, empatik dan santun pada sesama pendidik, tenaga kependidikan, orang tua dan masyarakat. 95,7\% mahasiswa setuju bahwa guru harus mampu berkomunikasi dan bergaul secara efektif dengan sesama pendidik dan tenaga kependidikan. Sedangkan 90,9\% mahasiswa setuju bahwa guru harus mampu berkomunikasi dan bergaul secara efektif dengan orang tua/wali peserta didik dan masyarakat sekitar.
\end{abstract}

Kata Kunci: Kompetensi Sosial, Mahasiswa PGSD

\section{PENDAHULUAN}

Menurut Undang-Undang Nomor 14 Tahun 2005 Tentang Guru dan Dosen, "Kompetensi adalah seperangkat pengetahuan, keterampilan, dan perilaku yang harus dimiliki, dihayati, dan dikuasai oleh guru atau dosen dalam melaksanakan tugas keprofesionalan".

Untuk memenuhi kompetensi tersebut, seorang guru harus sudah mempersiapkan diri jauh-jauh hari sejak menjalani pendidikan profesi guru. Seorang calon guru harus belajar memenuhi kriteria kompetensi guru sehingga dapat memenuhi kriteria kompetensi tersebut ketika mengajar nantinya.
Berdasarkan Undang-Undang Nomor 14 Tahun 2005 tentang Guru dan Dosen, pada pasal 10 ayat (1) menyatakan bahwa Kompetensi guru tersebut meliputi kompetensi pedagogik, kompetensi kepribadian, kompetensi sosial, dan kompetensi profesional yang diperoleh melalui pendidikan profesi”.

Kompetensi social adalah kemampuan guru sebagai bagian dari masyarakat untuk berkomunikasi dan bergaul secara efektif dengan peserta didik, sesama pendidik, tenaga kependidikan, orangtua peserta didik dan masyarakat sekitar (Standar Nasional Pendidikan, Pasal 28 ayat 3 butir d). Menurut Uno (2008) 
kompetensi social adalah kemampuan guru dalam berinteraksi social, baik dengan peserta didik, sesama guru, kepala sekolah, maupun masyarakat.

Kriteria kompetensi social menurut Priansa (2014) antara lain: 1) Obyektif dalam bertindak dan tidak diskriminatif, 2) Berkomunikasi secara efektif, empatik dan santun, 3) mampu beradaptasi di seluruh wilayah dimana ia bertugas, 4) memiliki kemampuan untuk berkomunikasi secara lisan maupun tulisan dengan komunitas profesi sendiri dan profesi lain.

Keterampilan berkomunikasi merupakan salah satu keterampilan yang mempengaruhi kinerja seorang guru (Wiyani, 2015). Kualitas komunikasi guru menjamin terjalinnya interaksi dengan seluruh komponen dalam suatu system sekolah. Ada dua macam interaksi dalam berkomunikasi yaitu: a) Interaksi dalam konteks tugas yang mengarahkan secara langsung pada tujuan pendidikan, b) Interaksi diluar konteks tugas yang dilakukan baik di sekolah maupun di luar sekolah. Untuk meningkatkan kinerja guru maka kedua macam interaksi tersebut harus dilakukan secara seimbang.

Sebagai calon guru maka mahasiswa PGSD Widya Gama Mahakam Samarinda harus memenuhi keempat kompetensi tersebut. Sesuai dengan visi dan misi Program Studi Pendidikan Guru Sekolah Dasar Universitas Widya Gama Mahakam Samarinda yang berbunyi "Menjadi Program Studi unggul yang mencetak guru sekolah dasar yang profesional..." Oleh karena itu, peneliti tertarik untuk melakukan penelitian yang berkaitan dengan kompetensi guru khususnya kompetensi sosial guru pada mahasiswa PGSD Widyagama Mahakam Samarinda.

Focus masalah dalam penelitian ini adalah: "Bagaimana pemahaman kompetensi Sosial pada mahasiswa PGSD Universitas Widya Gama Mahakam Samarinda?"
Penelitian ini bertujuan untuk mendeskripsikan penguasaan kompetensi Sosial mahasiswa PGSD UWGM.

\section{METODE PENELITIAN}

Penelitian ini dilaksanakan pada bulan Juli 2018 di FKIP PGSD Universitas Widya Gama Mahakam Samarinda pada mahasiswa PGSD angkatan 2015 dengan jumlah sampel mahasiswa sebanyak 94 orang.

Penelitian ini merupakan penelitian kualitatif. Jenis penelitian ini bersifat deskriptif, dimana penelitian ini diharapkan dapat menjelaskan fenomena yang ada, terutama yang berkaitan dengan kompetensi sosial mahasiswa PGSD Universitas Widya Gama Mahakam Samarinda sebagai calon guru Sekolah Dasar.

Dalam penelitian ini, teknik pengumpulan data yang digunakan adalah observasi, wawancara mendalam, dan dokumentasi. Teknik analisis data yang digunakan adalah teknik analisis Model Miles and Huberman. Aktivitas dalam analisis ini meliputi reduksi data (data reduction), penyajian data (data display) serta Penarikan kesimpulan dan verifikasi (conclusion drawing / verification).

\section{HASIL DAN PEMBAHASAN}

Penelitian ini dilaksanakan di Universitas Widya Gama Mahakam Samarinda pada mahasiswa Pendidikan Guru Sekolah Dasar dengan jumlah sampel 94 orang dari 133 orang mahasiswa angkatan 2015 yang aktif. 


\section{DAFTAR PUSTAKA}

Arifin. 2011. Kompetensi Guru dan Strategi Pengembangannya. Jakarta: Lilin Persada Press

Buchori, M., 2009. Evolusi Pendidikan di Indonesia. Yogyakarta: INSIST Press

Bungin, B., 2005. Metodologi Penelitian Kuantitatif. Jakarta: Kencana

Kunter, M., 2013. Professional Competence of Teachers: Effects on Instructional Quality and Student Development. Journal of Educational Psychology. [Online]. Diakses di

http://www.researchgate.net/pu blication (8 Oktober 2018).

Liakopoulou, M., 2011. The Professional Competence of Teachers: Which Qualities, Attitudes, Skills and Knowledge Contribute to a Teacher's Effectiveness?. International Journal of Humanities and Social Science. Vol. 1 No. 21. [Online]. Diakses di http://www.ijhssnet.com/journa

\section{1/vol_1_No_21 (8 Oktober 2018).}

Buck Institute for Education. Introduction to Project Based Learning. [Online]. Diakses di http://www.bie.org/about/what pbl (20 Desember 2017).

Nurdin, S. Dan Adriantoni. 2016. Kurikulum dan Pembelajaran. Jakarta: Raja Grafindo Persada.

Priansa, D.J. 2014. Kinerja dan Sosialisme Guru. Bandung: Alfabeta.

Rivai, V., dan Murni, S., 2012. Education Management, Analisis Teori dan Praktik. Jakarta: Raja Grafindo Persada.

Sugiyono, 2017. Metode Penelitian Pendidikan. Pendekatan Kuantitatif, Kualitatif, dan $R \& D$. Bandung: Alfabeta.

Sukmadinata, N.S. 2012. Metode Penelitian Pendidikan. Bandung: Rosdakarya.

Sutrisno, E. 2011. Manajemen Sumber Daya Manusia. Jakarta: Kencana

Suyanto dan Djihad, A. 2013. Bagaimana Menjadi Calon Guru dan Guru Sosial. Yogyakarta: Multi Pressindo. 